\title{
PROBLEMS AND PROSPECTS OF ORGANIC PRODUCTION IN FAMILY FARMING IN UKRAINE
}

\author{
YULIIA ZOLOTNYTSKA \\ OLEKSANDR OPALOV
}

\begin{abstract}
The article reveals the problems of organic farming in Ukraine. The study showed that small producers, such as family farms, have the ability to produce organic products in accordance with the appropriate requirements. A SWOT analysis of the process of organic farming by a private peasant household was conducted as well as the main opportunities and threats, strengths and weaknesses of its functioning and development were identified. The strategy of development of the Ukrainian organic agriculture of family farms has been chosen. It will give the chance to pursue it further by means of strategic directions, such as: tax incentives for producers of organic products, implementation of the state program for sustainable development of rural areas, "green" tourism and rural cooperation, elimination of political levers of influence on the implementation of state agricultural policy, as well as implementation of the state program to support the development of advisory services in the field of organic production.
\end{abstract}

Keywords: private peasant households, family farms, organic production, SWOT analysis, development strategy.

JEL codes: D13, Q12, Q13, R20.

Yuliia Zolotnytska, PhD, Assoc. Prof., Faculty of Economics and Management, Zhytomyr National Agroecological University; 7, Staryi blvd., Zhytomyr, Ukraine (zolotyuliya@ukr.net). ORCID iD: 0000-0002-9278-0707/

Oleksandr Opalov, PhD, Assoc. Prof., Faculty of Economics and Management, Zhytomyr National Agroecological University; 7, Staryi blvd., Zhytomyr, Ukraine (opsan@ukr.net). ORCID iD: 0000-0003-1984-8477) 


\section{Introduction}

The implementation of the global process of economic, political and cultural integration and unification has contributed to the growth of global competition, including the agricultural sector. Thus, prices and competitive conditions of the Ukrainian agricultural market have been inextricably linked with the relevant markets of other countries. At the present stage, one of the ways to increase the competitiveness of agricultural products is the production of organic products in Ukraine.

The United Nations Organization has declared 2019-2028 as the Decade of Family Farming. Scientific research made it possible to rethink and recognize the importance and diversity of small-scale commodity production in agricultural sector. Scientists have proved that family farming has a unique opportunity to ensure food security, rational use of natural resources and environmental protection, produce organic products, improve the living standards of rural population and achieve sustainable development of rural areas (Lukasik, 2011), (Arbenz et al., 2015). Unlike corporations, family farmers are real people; they have personal connection to their farms and to others in their communities. They feel an ethical responsibility to care for their land and care about their neighbors and customers (Ikerd, 2016).

The standards maintained by state governments and private organizations mainly define minimum requirements for organic production and processing. However, they often fail to meet the rules of health, ecology, fairness and care which are at the core of the organic philosophy entirely. According to scientists, it is due to exclusion of many producers who grow their products organically without an organic certification, namely households and peasant farmers, who play a critical role in feeding much of the world's population (Arbenz et al., 2016). Most farmers in the world are smallholders; they play a fundamental role in supporting the biodiversity.

Today, farmers face many difficulties, such as political instability, strong competition against the backdrop of global integration, strict environmental regulations and extreme climate change, as well as changes in consumer preferences and social expectations. The ability of farmers to meet these challenges depends on their adaptive capacity (Darnhofer et al., 2010).

The research on the adaptive potential and motivations of farmers to switch to organic farming showed that farmers regard organic farming as a way to enhance their adaptive capacity through four mechanisms: reducing risks, stimulating learning, increasing professional satisfaction, and enabling them to maintain their family farm. The mentality is changing. Even those who do not convert to organic farming think about reducing the use of chemicals. Thus, in the context of low and variable prices for conventional milk, organic farming is perceived as an opportunity, offering better prospects for the future (Bouttes et al., 2018). This is quite different from previous studies, in which organic farming was considered risky, often due to the lack of technical knowledge (Padel, 2001). 


\section{Identifying the problem}

In accordance with current legislation of Ukraine (Law of Ukraine No 436-IV, 2019), the agricultural sector is represented by various organizational and legal forms of management and enterprises of different sizes. Large and medium-sized enterprises are represented by private enterprises and limited liability companies. Farms and production cooperatives should be distinguished among small and micro enterprises.

The abovementioned list of business entities does not include another small in size, however, relatively significant form of management, i.e. private peasant households. As of 01.01.2020, there were 6.9 million owners of land shares, including 3.9 million of sole agricultural producers registered as private peasant households. The mentioned private peasant households cultivate 6.1 million hectares of agricultural land, which is $15.9 \%$ of the total agricultural land in Ukraine. In comparison, the largest 100 agricultural holdings also cultivate about 6.3 million hectares of land in Ukraine (State Statistics Service of Ukraine, 2019).

In accordance with the current legislation of Ukraine, the activities of these private peasant households do not apply to entrepreneurial activity (Law of Ukraine No 742-IV, 2015). Thus, until recently, family farming, as an individual activity of citizens, has had no legal and taxation framework.

The Law of Ukraine amending the Tax Code of Ukraine and Certain Laws of Ukraine on Stimulating the Formation and Activity of Family Farms dated 10.07.2018 No. 2497-VIII establishes the features of taxation, state support and state registration of family farms. However, today's peasants are held off registering as business entities; most of them are constrained to do so due to tax liabilities, misconceptions about their own financial benefits and lack of knowledge of accounting.

Regulatory and economic basis of production and turnover of organic agricultural products and raw materials is defined by the Law of Ukraine on Basic Principles and Requirements for Organic Production, Turnover and Marking of Organic Products (Law of Ukraine No 2496-VIII, 2018).

The Law fully takes into account the EU directives and regulations (Regulation (EU) 2018/848, Commission Regulation (EC) No 889/2008), which allowed to adapt the Ukrainian legislation to the European one. It improved requirements for the production, organic products labeling and turnover; radically changed the principles of production certification; requirements for certification bodies and inspectors have been significantly improved; specified responsibility for violations of legislation in the field of production, turnover and labeling of organic products, both for producers and for certification bodies, etc. In accordance with the mentioned regulatory act, the State Register of Organic Producers has been established in Ukraine. The databases of this Register are available for all market participants to carry out their business activities. Consumers of natural products can receive extensive and reliable information about producers of organic products, certification bodies, the availability of organic seeds and planting materials. 
Among the main market entities dealing with organic agricultural production, the largest share is held by private agricultural enterprises and limited liability companies, i.e. $73.5 \%$, the share of farms is $15.5 \%$, whereas the rest $-11 \%$ is held by natural entities - economic entities (Ministry of Agrarian Policy of Ukraine, 2020). Private agricultural enterprises and limited liability companies tend to specialize in growing of organic vegetables, grains and oilseeds. In addition to organic vegetables and grains, farms also grow organic berries. Natural entities - business entities predominantly specialize in the production of organic beekeeping products. However, there is not a single family farm among certified organic producers.

Table 1 presents the grouping of households in Ukraine by size of land plots.

Distribution of rural households by the land area in 2019 (\%)

Table 1

\begin{tabular}{lcc}
\hline $\begin{array}{c}\text { Households } \\
\text { with land area (ha): }\end{array}$ & $\begin{array}{c}\text { Distribution of rural households } \\
\text { by the area of land they use }\end{array}$ & $\begin{array}{c}\text { Reference: } \\
\text { distribution of the area of land } \\
\text { used by households by size }\end{array}$ \\
\hline $\mathbf{0 . 5 0}$ and less & 51.6 & 12.1 \\
$\mathbf{0 . 5 1 - 1 . 0 0}$ & 27.6 & 16.3 \\
$\mathbf{1 . 0 1 - 2 . 0 0}$ & 9.2 & 12.2 \\
$\mathbf{2 . 0 1}$ and more & 11.6 & 59.4 \\
2.01-5.00 & 8.0 & 16.7 \\
5.01-10.00 & 2.1 & 12.2 \\
10.01 and more & 1.5 & 30.5 \\
\hline
\end{tabular}

Source: State Statistics Service of Ukraine, 2019.

According to Table 1, 11.6\% (545200 units) of private farms own plots of two or more hectares, which is $59.4 \%$ of all agricultural land cultivated by peasant households or 4.1 million hectares. For comparison, the average area of organic farms was 36.6 hectares in European countries and 41.9 hectares in the European Union in 2018. The data obtained from the group of organic farms in the European Union show that the share of farms ranging from 2 to 9.99 hectares is about $27 \%$, and the share of farms ranging from 10 hectares to 19.99 hectares is $18 \%$ (Willer and Lernoud, 2019).

Thus, it is reasonable to believe that these private peasant households have optimal land plots for the production of organic products. The purpose of our research is to identify family farms' potential for their inclusion to the market of organic products. 


\section{The position of private peasant households in the agricultural sector of Ukraine}

Organic production is an overall system of farm management and food production that combines best environmental practices, a high level of biodiversity, the preservation of natural resources, the application of high animal welfare standards and a production method in line with the preference of certain consumers for products produced using natural substances and processes (Regulation (EU) 2018/848).

According to the Ministry of Agrarian Policy, there are 675 organic market operators in Ukraine today. 501 of them are producers, the rest are either traders, processors or purchasers of the so-called wild crop. The total area of certified organic agricultural land in 2018 amounted to 421 thousand hectares $(1 \%$ of the total agricultural land of Ukraine). Over the past five years, the total area of organic agricultural land in Ukraine has increased by 1.5 times (Ministry of Agrarian Policy of Ukraine, 2020).

In 2018, about $85 \%$ of Ukrainian organic products were exported. The export profit amounted to about EUR 99,7 million. The main exporters are the EU and Switzerland, along with the USA, Australia, Canada, and Asian countries constituting a slightly smaller part thereof. The main export products are grains, oilseeds, legumes, berries, fruits and wild crops (Willer and Lernoud, 2019). Sunflower meal, flour, sunflower oil, sunflower seed, apple concentrate, nuts and birch juice are also exported. In 2018, domestic consumer market for organic products in Ukraine was EUR 29.4 million and consumption per capita EUR 0.68 (for comparison: an average European consumer spends EUR 40.8 per year on organic products, while the EU citizen spends EUR 60.5).

In terms of the total area of agricultural land certified as organic, Ukraine is ranked $11^{\text {th }}$ among European countries and $20^{\text {th }}$ in the world. At the same time, almost half of the organic land is occupied by grain growing $(45.4 \%)\left(8^{\text {th }}\right.$ place among the major producing countries of organic products in the world). More than $18 \%$ of such land was occupied by oil crops ( $4^{\text {th }}$ place) and $5.3 \%$ by legumes $\left(7^{\text {th }}\right.$ place $)$, which are are followed by vegetables $-1.6 \%\left(10^{\text {th }}\right.$ place $)$ and fruits $0.7 \%$. Experts estimate that the growth rate of domestic organic production is by 5.5 times higher than that in European countries, and by 4.9 times higher than that in the world (Ministry of Agrarian Policy of Ukraine, 2020). Thus, Ukraine has a considerable potential in increasing the volumes of production and sales of organic products both on domestic and foreign markets.

Harvesting of agricultural crops in Ukraine is analyzed in Tables 2 and 3 in the context of agricultural enterprises and private peasant households. 
Table 2

Harvesting of agricultural crops in Ukraine by November 01, 2019

\begin{tabular}{|c|c|c|c|c|c|c|}
\hline \multirow{2}{*}{ Agricultural crops } & \multicolumn{2}{|c|}{$\begin{array}{l}\text { Harvested area } \\
\text { (thousand ha) }\end{array}$} & \multicolumn{2}{|c|}{$\begin{array}{l}\text { Volume of production } \\
\text { (thousand centner) }\end{array}$} & \multicolumn{2}{|c|}{$\begin{array}{l}\text { Yield, centner per ha } \\
\text { of the harvested area }\end{array}$} \\
\hline & 2019 & $\begin{array}{l}2019 \% \\
\text { to } 2018\end{array}$ & 2019 & $\begin{array}{l}2019 \% \\
\text { to } 2018\end{array}$ & 2019 & $\begin{array}{l}2019 \% \\
\text { to } 2018\end{array}$ \\
\hline \multicolumn{7}{|c|}{ All agricultural holdings } \\
\hline Cereal and leguminous crops & 14340.4 & 105.6 & 691361.9 & 114.4 & 48.2 & 108.3 \\
\hline Sunflower seeds & 5759.9 & 97.2 & 149234.4 & 107.5 & 25.9 & 110.7 \\
\hline Sugar beet (for processing) & 166.3 & 82.4 & 70487.5 & 74.3 & 423.9 & 90.2 \\
\hline Potatoes & 1307.7 & 99.2 & 202233.8 & 90.0 & 154.6 & 90.7 \\
\hline Vegetables & 440.4 & 102.4 & 89643.8 & 103.1 & 203.6 & 100.6 \\
\hline Fodder corn & 213.4 & 94.1 & 53578.9 & 91.3 & 251.5 & 97.1 \\
\hline Fruits and berries & $\mathrm{x}$ & $x$ & 19901.0 & 85.6 & $x$ & $\mathrm{x}$ \\
\hline \multicolumn{7}{|c|}{ Agricultural enterprises } \\
\hline Cereal and leguminous crops & 10242.0 & 107.3 & 537999.3 & 116.1 & 52.5 & 108.2 \\
\hline Sunflower seeds & 4657.8 & 96.5 & 127207.6 & 107.1 & 27.3 & 111.0 \\
\hline Sugar beet (for processing) & 150.4 & 81.8 & 65029.8 & 73.6 & 432.5 & 90.0 \\
\hline Potatoes & 14.9 & 98.7 & 3395.5 & 86.8 & 222.6 & 87.9 \\
\hline Vegetables & 29.2 & 105.2 & 11467.5 & 104.0 & 392.3 & 98.9 \\
\hline Fodder corn & 194.6 & 93.3 & 49954.4 & 91.3 & 256.7 & 97.9 \\
\hline Fruits and berries & $\mathrm{x}$ & $x$ & 2569.2 & 73.3 & $x$ & $\mathrm{x}$ \\
\hline \multicolumn{7}{|c|}{ Private peasant households } \\
\hline Cereal and leguminous crops & 4098.4 & 101.7 & 153362.6 & 108.8 & 37.4 & 106.9 \\
\hline Sunflower seeds & 1102.1 & 100.4 & 22026.8 & 110.0 & 20.0 & 109.9 \\
\hline Sugar beet (for processing) & 15.9 & 88.6 & 5457.7 & 83.9 & 342.9 & 94.7 \\
\hline Potatoes & 1292.8 & 99.2 & 198838.3 & 90.0 & 153.8 & 90.8 \\
\hline Vegetables & 411.2 & 102.2 & 78176.3 & 102.9 & 190.2 & 100.7 \\
\hline Fodder corn & 18.8 & 103.2 & 3624.5 & 92.3 & 196.6 & 89.4 \\
\hline Fruits and berries & $\mathrm{x}$ & $\mathrm{x}$ & 17331.8 & 87.7 & $\mathrm{x}$ & $\mathrm{x}$ \\
\hline
\end{tabular}

Source: State Statistics Service of Ukraine

According to Table 2, the yield of crop products grown by agricultural enterprises is much higher than that of peasant farms. Thus, the yield of cereals and legumes is higher by $28.8 \%$, sunflowers by $26.7 \%$, potatoes by $31 \%$, vegetables by $51.5 \%$, sugar beets by $20.7 \%$. This is due to the fact that agricultural enterprises use intensive technologies of cultivation and tillage.

In the last three years, private peasant households tended to increase the area under cereals and legumes, open-ground vegetables and fodder corn. These crops serve as a fodder base for livestock, which is common for private peasant farms. 
Table 3

Production of animal products in Ukraine

\begin{tabular}{|c|c|c|c|c|c|c|c|c|c|}
\hline \multirow{4}{*}{ Animal products } & \multicolumn{3}{|c|}{$\begin{array}{l}\text { All agricultural } \\
\text { holdings }\end{array}$} & \multicolumn{3}{|c|}{$\begin{array}{l}\text { Agricultural } \\
\text { enterprises }\end{array}$} & \multicolumn{3}{|c|}{$\begin{array}{c}\text { Private peasant } \\
\text { households }\end{array}$} \\
\hline & \multirow{3}{*}{2019} & \multirow{3}{*}{2018} & \multirow{3}{*}{$\begin{array}{l}2019 \\
\% \\
\text { to } \\
2018\end{array}$} & \multirow{3}{*}{2019} & \multirow{3}{*}{2018} & \multirow{3}{*}{$\begin{array}{c}2019 \\
\% \\
\text { to } \\
2018 \\
\end{array}$} & \multirow{3}{*}{2019} & \multirow{3}{*}{2018} & \multirow{3}{*}{$\begin{array}{c}2019 \\
\% \\
\text { to } \\
2018\end{array}$} \\
\hline & & & & & & & & & \\
\hline & & & & & & & & & \\
\hline $\begin{array}{l}\text { Livestock } \\
\text { for slaughter } \\
\text { (in live weight, } \\
\text { thousand tons) }\end{array}$ & 3492.7 & 3317.6 & 105.3 & 2299.6 & 2079.2 & 110.6 & 1193.1 & 1238.4 & 96.3 \\
\hline $\begin{array}{l}\text { Production of milk } \\
\text { (thousand tons) }\end{array}$ & 9697.0 & 10064.0 & 96.4 & 2727.8 & 2755.5 & 99.0 & 6969.2 & 7308.5 & 95.4 \\
\hline $\begin{array}{l}\text { Production of eggs } \\
\text { (million pieces) }\end{array}$ & 16676.6 & 16132.0 & 103.4 & 9357.6 & 8900.3 & 105.1 & 7319.0 & 7231.7 & 101.2 \\
\hline
\end{tabular}

Source: State Statistics Service of Ukraine

According to the results of 2019 , meat production increased by 175.1 thousand tons compared to 2018 and amounted to 3.5 million tons. This year, there has been an increase in meat production mainly by agricultural enterprises, while the production in households has slightly decreased.

The dairy industry in Ukraine is characterized by a negative trend. The number of cattle is decreasing every year. In 2019, the lowest number of cattle in the history of Ukraine was observed. For example, the number of dairy cows was about 1.9 million. On the other hand, the decrease is smaller comparing to the previous year, so we can talk about a slowdown in reduction of livestock.

Reducing the number of dairy cows leads to a decrease in the amount of milk. In 2019, Ukraine produced about 9.7 million tons of milk, which is by $3.6 \%$ less compared to the production in the same period in 2018. The decline in production was observed mainly in peasant households, while production in agricultural enterprises showed almost no change.

The production structure of main types of agricultural products of crop and livestock is analyzed in Figure 1.

Figure 1 shows that agricultural production in Ukraine specializes mainly in growing of grain and legumes (77\%), sugar beet (95\%) and sunflower (86\%). This is due to the fact that these crops are highly profitable. In addition, large agricultural enterprises have a high-tech equipment and powerful agricultural machinery, which allows them to achieve greater productivity and productive efficiency.

The leading position in the production of meat in slaughter weight and eggs is occupied by large agricultural enterprises: $64.0 \%$ and $53.9 \%$, respectively. 


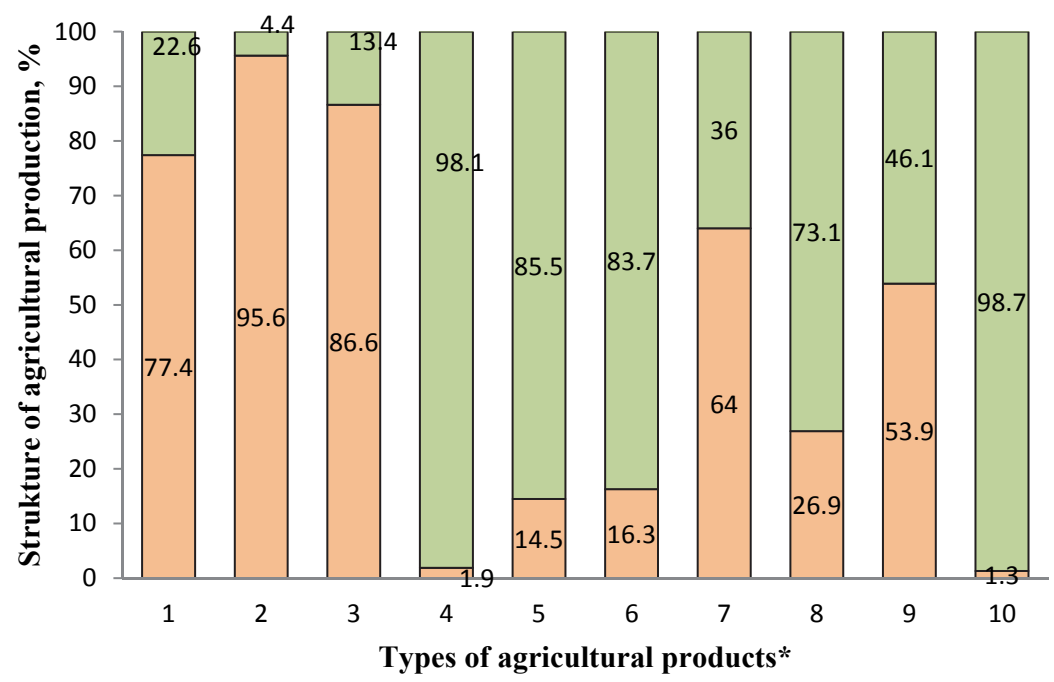

$\square$ Agricultural enterprises $\quad \square$ Private peasant households

Fig. 1. Structure of production of the main types of crop and livestock products in Ukraine.

* 1 - Grain and leguminous crops; 2 - Industrial sugar beets; 3 - Sunflower; 4 - Potatoes; 5 - Vegetables; 6 - Fruits and berries; 7 - Meat; 8 - Milk; 9 - Eggs; 10 - Honey

Source: State Statistics Service of Ukraine, 2019.

The most labor-intensive industries, such as potato and vegetable growing, fruit and berry growing, are almost entirely attributable to peasant households (from $98.1 \%$ to $83.7 \%$, respectively). Family peasant households specialize in dairy cattle rearing and provide milk (73.1\%), meat (36.0\%) and honey $(98.7 \%)$. During 9 months of 2019, Ukraine exported 46,200 tons of honey worth \$ 86.9 million. This is a record volume compared to the same period in previous years, according to data from the Food and Agriculture Organization of the United Nations (FAO). The largest amount of honey was bought by the USA (\$23.2 million), Germany (\$21.1 million) and Poland (\$12.3 million). The share of these countries accounts for over 65\% of export (State Fiscal Service of Ukraine, 2019).

Thus, family households promote the employment of rural people and remain a stabilizing link of management, which compensates the decline in agricultural production in certain sectors. Family farms meet the food needs of the population and make cash income of rural people.

According to the data presented in the Tables and Figure above, it is evident that family peasant households are rather a significant element of agricultural complex of Ukraine, since they produce about $43.6 \%$ of the total volume of agricultural products. Family households are a truly "Ukrainian phenomenon" and play an important role in the country's food security.

Prospects for the organic farming development in Ukraine will be explored on the basis of the SWOT analysis. 
Compared to other methods, the main advantage of the SWOT analysis, is the ability to process a significant amount of information to determine the current state and directions of object's development. At the same time, due to the procedure of dichotomous analysis, it is possible to obtain fairly accurate qualitative estimates of external and internal factors that both positively and negatively affect the functioning and development of the object.

Thus, this method will identify strengths and weaknesses, as well as opportunities for and threats to the development of organic production by family farms (Tables 4 and 5).

Table 4

Strengths and weaknesses of private peasant farms for the development of organic farming in Ukraine

\begin{tabular}{|c|c|c|}
\hline Parameters & Strong points & Weak points \\
\hline \multirow{3}{*}{$\begin{array}{l}\text { Availability } \\
\text { of resources }\end{array}$} & $\begin{array}{l}S_{1}-\text { Sufficient areas of agricultural } \\
\text { land in farming }\end{array}$ & $\begin{array}{l}W_{1}-\text { Low provision of peasant farms } \\
\text { with financial resources }\end{array}$ \\
\hline & $\begin{array}{l}S_{2}-\text { The optimal size of land holdings } \\
\text { of peasant farms }\end{array}$ & $\begin{array}{c}W_{2}-\text { Low provision of peasant farms } \\
\text { with means of labor }\end{array}$ \\
\hline & $S_{3}-$ No need for hired labor & \\
\hline \multirow{2}{*}{$\begin{array}{l}\text { Compliance } \\
\text { with quality } \\
\text { parameters } \\
\text { and technology }\end{array}$} & $\begin{array}{l}S_{4}-\text { Experience in agriculture } \\
\text { without herbicides and pesticides } \\
\text { utilization }\end{array}$ & $\begin{array}{l}W_{3}-\text { Lack of knowledge of villagers } \\
\text { in advanced methods and } \\
\text { technologies of organic production }\end{array}$ \\
\hline & $\begin{array}{l}S_{5}-\text { The actual compliance of most } \\
\text { products with quality standards } \\
\text { of organic production }\end{array}$ & $\begin{array}{l}W_{4}-\text { Insecurity of peasants in their } \\
\text { own ability to switch to organic } \\
\text { production and fear of possible } \\
\text { challenges }\end{array}$ \\
\hline $\begin{array}{l}\text { Access to } \\
\text { organized } \\
\text { market }\end{array}$ & $\begin{array}{l}S_{6}-\text { Communication with potential } \\
\text { buyers and advertising of own } \\
\text { products through the Internet }\end{array}$ & $\begin{array}{l}W_{5} \text { - Lack of appropriate culture } \\
\text { and work ethic among peasants } \\
\text { in associations and unions }\end{array}$ \\
\hline
\end{tabular}

Source: own research.

The information basis for the SWOT analysis was as follows:

- statistical and analytical information used to identify internal and external factors influencing the development of organic farming in private peasant farms;

- the results of the survey of experts in organic production and farming, used to assess the opportunities for and threats to the development of organic farming in private peasant farms.

The list of these strengths and weaknesses of private peasant farms in relation to their transition to organic production is fully consistent with the above material and existing research in this area (Senyshyn et al., 2018). 
Table 5

Opportunities for and threats to the external environment for the development of organic farming in private peasant farms in Ukraine

\begin{tabular}{|c|c|c|}
\hline Parameters & Opportunities & Threats \\
\hline Demand & $\begin{array}{l}O_{1}-\text { High domestic demand for organic } \\
\text { products through the promotion } \\
\text { of a healthy lifestyle }\end{array}$ & $\begin{array}{l}T_{1}-\text { Low solvency of the population } \\
\text { as a factor in reducing demand } \\
\text { for more expensive organic products }\end{array}$ \\
\hline Competition & $\begin{array}{l}\mathrm{O}_{2}-\text { Low cost of products grown } \\
\text { on private peasant farms }\end{array}$ & $\begin{array}{l}T_{2}-\text { High level of competition among } \\
\text { producers of organic products } \\
\text { in foreign markets }\end{array}$ \\
\hline \multirow{3}{*}{$\begin{array}{l}\text { Policy of state } \\
\text { support } \\
\text { for the } \\
\text { development } \\
\text { of organic } \\
\text { farming } \\
\text { in Ukraine }\end{array}$} & $\begin{array}{l}O_{3} \text { - Optimal tax policy of the state, } \\
\text { in general, and in the agricultural } \\
\text { sector, in particular }\end{array}$ & $\begin{array}{l}T_{3} \text { - Lack of knowledge of rural people } \\
\text { about the potential benefits } \\
\text { of tax self-identification } \\
\text { and organic farming }\end{array}$ \\
\hline & $\begin{array}{l}\mathrm{O}_{4} \text { - Increase in state financial support } \\
\text { for farmers who grow organic } \\
\text { products }\end{array}$ & $\begin{array}{l}T_{4}-\text { Powerful lobby of large agricultural } \\
\text { holdings in the Parliament and } \\
\text { government of Ukraine }\end{array}$ \\
\hline & $\begin{array}{l}O_{5}-\text { State program for rural development, } \\
\text { "green" tourism and rural } \\
\text { cooperation }\end{array}$ & $\begin{array}{l}T_{5} \text { - Lack of state support for the provision } \\
\text { of advisory services } \\
\text { in organic production }\end{array}$ \\
\hline $\begin{array}{l}\text { Social and } \\
\text { demographic } \\
\text { situation }\end{array}$ & $\begin{array}{l}\mathrm{O}_{6} \text { - The reform of decentralization } \\
\text { and community development } \\
\text { in rural areas }\end{array}$ & $\begin{array}{l}T_{6} \text { - Labor migration of rural people } \\
\text { and the demographic crisis }\end{array}$ \\
\hline $\begin{array}{l}\text { Nature } \\
\text { and ecology }\end{array}$ & $\begin{array}{l}\mathrm{O}_{7}-\text { Favorable weather-climatic } \\
\text { conditions and satisfactory state } \\
\text { of ecology of the environment } \\
\text { for organic farming }\end{array}$ & $T_{7}$ - Global climate change \\
\hline
\end{tabular}

Source: own research.

The results of a survey conducted among rural residents on their attitude to the prospects for the development of private peasant farms under agrarian reform are rather indicative. About $90 \%$ of all peasants surveyed associate their lives with agricultural activities. The majority of rural residents (more than 65\%) express a desire to expand their homesteads and receive additional land shares, as well as they are ready to move to market principles of labor organization (Bulavka, 2012).

When assessing opportunities and threats, we will use a five-point rating scale:

5 - very strong positive impact;

4 - strong positive impact;

3 - average positive impact;

2 - positive impact below average;

1 - weak positive impact;

0 - no positive effect. 
Table 6

Assessment of opportunities for organic production by family peasant farms in Ukraine

\begin{tabular}{|c|c|c|c|c|c|c|c|c|c|c|c|c|c|c|c|}
\hline \multirow{3}{*}{ Opportunities } & \multicolumn{14}{|c|}{ Experts } & \multirow{3}{*}{ 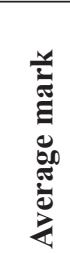 } \\
\hline & \multicolumn{2}{|c|}{ No. 1} & \multicolumn{2}{|c|}{ No. 2} & \multicolumn{2}{|c|}{ No. 3} & \multicolumn{2}{|c|}{ No. 4} & \multicolumn{2}{|c|}{ No. 5} & \multicolumn{2}{|c|}{ No. 6} & \multicolumn{2}{|c|}{ No. 7} & \\
\hline & $\begin{array}{l}\tilde{\tilde{y}} \\
\stackrel{\vec{Z}}{\tilde{\Xi}}\end{array}$ & $\frac{\tilde{y}}{\tilde{E}}$ & 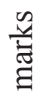 & $\frac{n}{\tilde{E}}$ & 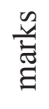 & $\underline{\tilde{y}}$ & 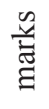 & $\frac{\tilde{y}}{\mathbb{E}}$ & $\begin{array}{l}\frac{\tilde{y}}{\vec{Z}} \\
\stackrel{\Xi}{\Xi}\end{array}$ & $\begin{array}{l}\text { 光 } \\
\text { 렌 }\end{array}$ & $\begin{array}{l}\tilde{y} \\
\stackrel{\Xi}{\Xi} \\
\Xi\end{array}$ & $\frac{\tilde{y}}{\tilde{E}}$ & $\begin{array}{l}\tilde{y} \\
\stackrel{y}{Z}\end{array}$ & $\frac{n}{\tilde{E}}$ & \\
\hline $\mathrm{O}_{1}$ & 5 & 4 & 5 & 3 & 4 & 4 & 4 & 4 & 5 & 3 & 3 & 3 & 4 & 4 & 15.3 \\
\hline $\mathrm{O}_{2}$ & 4 & 3 & 4 & 3 & 3 & 2 & 3 & 2 & 3 & 1 & 4 & 3 & 4 & 4 & 9.6 \\
\hline $\mathrm{O}_{3}$ & 5 & 4 & 4 & 4 & 5 & 4 & 5 & 4 & 4 & 4 & 4 & 3 & 4 & 3 & 16.6 \\
\hline $\mathrm{O}_{4}$ & 5 & 3 & 5 & 3 & 5 & 3 & 4 & 2 & 5 & 3 & 4 & 3 & 5 & 3 & 13.6 \\
\hline $\mathrm{O}_{5}$ & 4 & 4 & 4 & 3 & 5 & 4 & 5 & 4 & 5 & 3 & 5 & 4 & 4 & 4 & 17.0 \\
\hline $\mathrm{O}_{6}$ & 3 & 2 & 4 & 2 & 3 & 2 & 5 & 3 & 4 & 3 & 4 & 3 & 3 & 2 & 9.3 \\
\hline $\mathrm{O}_{7}$ & 5 & 5 & 5 & 4 & 4 & 4 & 5 & 5 & 4 & 4 & 5 & 4 & 5 & 4 & 20.3 \\
\hline
\end{tabular}

Source: own research.

To select the dominant capabilities (O), we should multiply the positive effect that can be obtained as a result of the opportunity implementation and the probability of its occurrence.

Similarly, we will assess the threats to the development of organic farming by family peasant farms (Table 7).

Table 7

Assessment of threats to the organic production by family peasant farms in Ukraine

\begin{tabular}{|c|c|c|c|c|c|c|c|c|c|c|c|c|c|c|c|}
\hline \multirow{3}{*}{ Threats } & \multicolumn{14}{|c|}{ Experts } & \multirow{3}{*}{ 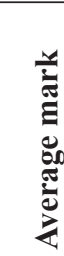 } \\
\hline & \multicolumn{2}{|c|}{ No. 1} & \multicolumn{2}{|c|}{ No. 2} & \multicolumn{2}{|c|}{ No. 3} & \multicolumn{2}{|c|}{ No. 4} & \multicolumn{2}{|c|}{ No. 5} & \multicolumn{2}{|c|}{ No. 6} & \multicolumn{2}{|c|}{ No. 7} & \\
\hline & $\begin{array}{l}\tilde{y} \\
\tilde{\Xi}\end{array}$ & $\frac{\tilde{y}}{\mathbb{E}}$ & $\begin{array}{l}\tilde{y} \\
\bar{Z} \\
\tilde{E}\end{array}$ & $\frac{\tilde{y}}{\mathbb{E}}$ & $\begin{array}{l}\tilde{y} \\
\bar{Z} \\
\tilde{\Xi}\end{array}$ & 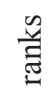 & 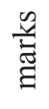 & $\frac{\tilde{y}}{\mathbb{E}}$ & $\begin{array}{l}\tilde{y} \\
\bar{\Xi} \\
\Xi\end{array}$ & $\frac{\tilde{y}}{\mathbb{E}}$ & $\begin{array}{l}\tilde{y} \\
\bar{Z} \\
\tilde{\Xi}\end{array}$ & $\frac{\tilde{y}}{\mathbb{E}}$ & $\begin{array}{l}\tilde{y} \\
\bar{Z} \\
\tilde{Z}\end{array}$ & $\frac{\mathscr{y}}{\tilde{E}}$ & \\
\hline $\mathrm{T}_{1}$ & 4 & 3 & 3 & 3 & 3 & 2 & 4 & 4 & 4 & 4 & 5 & 3 & 3 & 3 & 11.9 \\
\hline $\mathrm{T}_{2}$ & 3 & 2 & 3 & 3 & 4 & 3 & 4 & 2 & 2 & 2 & 3 & 3 & 2 & 2 & 7.4 \\
\hline $\mathrm{T}_{3}$ & 3 & 2 & 3 & 1 & 2 & 1 & 2 & 2 & 3 & 2 & 3 & 3 & 2 & 1 & 4.6 \\
\hline $\mathrm{T}_{4}$ & 5 & 5 & 4 & 5 & 5 & 4 & 5 & 5 & 4 & 4 & 5 & 3 & 5 & 4 & 20.1 \\
\hline $\mathrm{T}_{5}$ & 5 & 5 & 5 & 4 & 5 & 4 & 4 & 4 & 5 & 5 & 5 & 4 & 4 & 4 & 20.3 \\
\hline $\mathrm{T}_{6}$ & 5 & 5 & 5 & 4 & 5 & 4 & 5 & 5 & 5 & 4 & 5 & 5 & 5 & 5 & 22.9 \\
\hline $\mathrm{T}_{7}$ & 4 & 3 & 3 & 2 & 3 & 3 & 4 & 3 & 4 & 2 & 3 & 3 & 3 & 3 & 9.3 \\
\hline
\end{tabular}

Source: own research. 
When assessing the threats, we used a five-point rating scale:

5 - very strong negative impact;

4 - strong negative impact;

3 - average negative impact;

2 - negative impact below average;

1 - weak negative impact;

0 - no negative impact.

In order to visualize the assessment of opportunities and threats, we use the graphical method (Fig. 2).

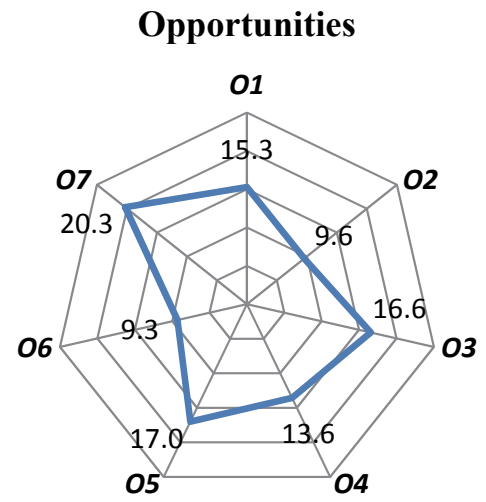

Opportunities

\section{Threats}

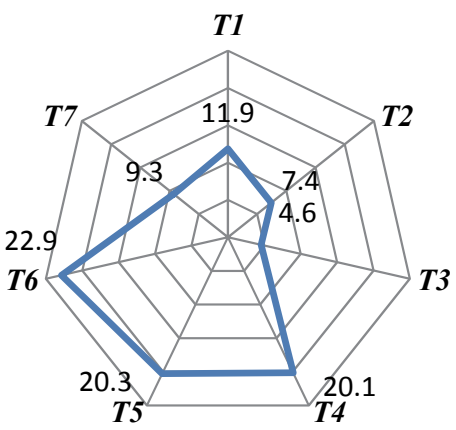

Threats

Fig. 2. Diagrams of opportunities and threats to the development of organic production of private peasant farms in Ukraine.

Source: own research.

Thus, the most likely and influential positive opportunities are as follows:

$\mathrm{O}_{3}$ - optimal tax policy of the state in general, and the agricultural sector, in partif cular;

$\mathrm{O}_{5}$ - state program for rural development, "green" tourism and rural cooperation;

$\mathrm{O}_{7}$ - favorable weather-climatic conditions and satisfactory state of ecology of the environment for organic farming.

The results of the threat assessment show that the most influential threats are as follows:

$\mathrm{T}_{4}$ - a powerful lobby of large agricultural holdings in the Parliament and governe ment of Ukraine;

$\mathrm{T}_{5}$ - lack of state support for the provision of advisory services in organic production;

$\mathrm{T}_{6}$ - labor migration of able-bodied rural population and demographic crisis.

The next step of the strategic analysis of the prospects for the development of organic farming in Ukraine by family peasant farms is to build a matrix of SWOT analysis with SO, ST, WO and WT strategies (Table 8). 
Table 8

Matrix of SWOT analysis showing the relationship of the external environment with the strengths and weaknesses of the organic farming development

\begin{tabular}{|c|c|c|}
\hline Strong points & SO strategies & ST strategies \\
\hline $\begin{array}{l}S_{1}-\text { Sufficient areas } \\
\text { of agricultural land } \\
\text { in farming }\end{array}$ & $\begin{array}{l}\mathrm{O}_{6}-\text { The reform of decentralization } \\
\text { and community development } \\
\text { in rural areas }\end{array}$ & $\begin{array}{c}T_{4}-\text { Powerful lobby of large } \\
\text { agricultural holdings } \\
\text { in the Parliament and } \\
\text { government of Ukraine }\end{array}$ \\
\hline $\begin{array}{r}S_{2}-\text { The optimal size } \\
\text { of land holdings } \\
\text { of peasant farms }\end{array}$ & $\begin{array}{l}O_{5}-\text { State program for rural } \\
\text { development, ,green” tourism } \\
\text { and rural cooperation }\end{array}$ & $\begin{array}{l}T_{3}-\text { Lack of knowledge of rural } \\
\text { people about the potential } \\
\text { benefits of tax self-identification } \\
\text { and organic farming }\end{array}$ \\
\hline $\begin{array}{l}S_{3}-\text { No need } \\
\quad \text { for hired labor }\end{array}$ & $\begin{array}{l}\mathrm{O}_{2}-\text { Low cost of products grown } \\
\text { in private peasant farms }\end{array}$ & $\begin{array}{l}T_{6}-\text { Labor migration of rural people } \\
\text { and the demographic crisis }\end{array}$ \\
\hline $\begin{array}{l}S_{4}-\text { Experience } \\
\text { in agriculture } \\
\text { without herbicides } \\
\text { and pesticides } \\
\text { utilization }\end{array}$ & $\begin{array}{l}O_{7}-\text { Favorable weather-climatic } \\
\text { conditions and satisfactory state } \\
\text { of ecology of the environment } \\
\text { for organic farming; } \\
O_{3} \text { - Optimal tax policy of the state } \\
\text { in general, and in the agricultural } \\
\text { sector in particular }\end{array}$ & $T_{7}-$ Global climate change \\
\hline $\begin{array}{l}S_{5}-\text { Most products } \\
\text { actual compliance } \\
\text { with quality } \\
\text { standards } \\
\text { of organic } \\
\text { production }\end{array}$ & $\begin{array}{l}\mathrm{O}_{4}-\text { Increase in state financial } \\
\text { support for farmers } \\
\text { who grow organic products }\end{array}$ & $\begin{array}{l}T_{5}-\text { Lack of state support } \\
\text { for the provision of advisory } \\
\text { services in organic production; } \\
T_{1}-\text { Low solvency of the population } \\
\text { as a factor in reducing demand } \\
\text { for more expensive organic } \\
\text { products }\end{array}$ \\
\hline
\end{tabular}

$S_{6}$ - Communication $O_{1}-$ High domestic demand with potential buyers for ecological products due and advertising to the promotion of a healthy of own production lifestyle via Internet
$T_{2}$ - High level of competition among producers of organic products in foreign markets

\begin{tabular}{|c|c|c|}
\hline Weak points & WO strategies & WT strategies \\
\hline $\begin{array}{l}W_{1}-\text { Low provision } \\
\text { of peasant farms } \\
\text { with financial } \\
\text { resources }\end{array}$ & $\begin{array}{l}\mathrm{O}_{2}-\text { Low cost of products grown } \\
\text { in private peasant farms; } \\
\mathrm{O}_{3} \text { - Optimal tax policy of the state } \\
\text { in general, and in the agricultural } \\
\text { sector in particular; } \\
\mathrm{O}_{4} \text { - Increase in state financial support } \\
\text { for farmers who grow organic } \\
\text { products }\end{array}$ & $\begin{aligned} T_{3}- & \text { Lack of knowledge of rural } \\
& \text { people in the potential benefits } \\
& \text { of tax self-identification } \\
& \text { and organic farming; } \\
T_{4}- & \text { Powerful lobby of agricultural } \\
& \text { holdings in the Parliament } \\
& \text { and government of Ukraine }\end{aligned}$ \\
\hline $\begin{array}{l}W_{2}-\text { Low provision } \\
\text { of peasant farms } \\
\text { with means of labor }\end{array}$ & $\begin{array}{l}\mathrm{O}_{4}-\text { Increase in state financial support } \\
\text { for farmers who grow organic } \\
\text { products }\end{array}$ & $\begin{array}{l}T_{6}-\text { Labor migration of rural people } \\
\text { and the demographic crisis }\end{array}$ \\
\hline $\begin{array}{l}W_{3} \text { - Ignorance } \\
\text { of rural residents } \\
\text { in advanced methods } \\
\text { and technologies } \\
\text { of organic farming }\end{array}$ & $\begin{array}{l}\text { conditions and satisfactory state } \\
\text { of ecology of the environment } \\
\text { for organic farming }\end{array}$ & $\begin{array}{l}T_{5}-\text { Lack of state support } \\
\text { for the provision of advisory } \\
\text { services in organic production; } \\
T_{7}-\text { Global climate change }\end{array}$ \\
\hline
\end{tabular}


cont. Table 8
$W_{4}$ - Peasants' insecurity $O_{1}-$ High domestic demand for in their own ability ecological products due to the to switch to organic promotion of a healthy lifestyle; production and $\mathrm{O}_{4}$ - Increase in state financial support fear of possible challenges

$T_{1}-$ Low solvency of the population as a factor in reducing demand for more expensive organic products;

$T_{2}$ - High level of competition among producers of organic products in foreign markets

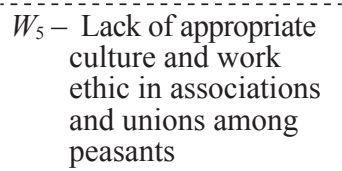

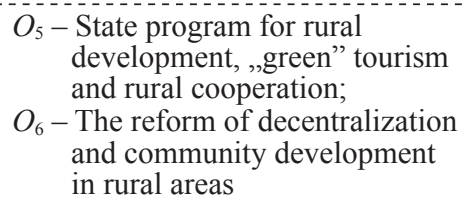

$T_{5}$ - Lack of state support

for the provision of advisory services in organic production

Source: own research.

\section{Research results}

Analysis of the SWOTmatrix with SO, ST, WO and WT directions allowed to outline the most optimal strategies for the development of organic farming by private peasant farms, namely:

1) strategy of organizational change (this strategy involves changing the organizational structure of private farming and its transition to the legal field as an official business entity, i.e. the establishment of a family farm);

2) product-market reorientation strategy (this strategy envisages the transition of newly created family farms to the production of organic products).

However, the effectiveness of these strategies will depend on certain actions taken by the state to support family farming. Therefore, in our opinion, in order to stimulate the development of organic production in Ukraine, it is necessary:

1) to fix financial support of family peasant households and farms by the state at a legislative level, especially during a transition period;

2) to introduce free training seminars for rural men and farmers who decide to switch to production of organic products (raw materials);

3) for competent authorities to develop (adapt) a set of technical and economic documentation for organic production by family peasant households and family farms.

The implementation of the proposed measures will not only increase the volume of organic production in Ukraine, but also develop potential of family peasant households and family farms, and it will contribute to the growth of farmers' incomes and sustainable development of rural areas. 


\section{Summary and conclusions}

The research showed that about 545 thousand of private peasant farms have optimal-sized land plots with a total area of 4.1 million hectares. The total share of private peasant farms in the structure of commodity agricultural production in Ukraine is $43.6 \%$. In Ukraine, private peasant farms have been engaged for decades in less profitable, but important industries, such as: beekeeping, dairy and beef cattle rearing, vegetable, fruit and berry growing. Under market conditions for agricultural production in Ukraine, family peasant households are not able to compete with high-value producers for markets. Peasant households are also losing in competitive struggle in terms of volumes, intensity and production efficiency. However, peasant households and family farms have unquestionable advantages over high-value producers against the backdrop of both domestic and external demand for organic products.

The activity of family peasant households is primarily aimed at providing the family with food for own needs and also for sale. Production by family farms can be described as rather diversified: practically on every farm vegetables, cereals, fruits and berries are grown, birds, pigs, cattle, horses, goats and sheep, rabbits, etc., are raised. This allows for practically a non-waste production, since waste from one production becomes food or fertilizer for another one. Such closed organic production cycle creates a kind of natural ecosystem and contributes to ecological waste management.

Family peasant households use predominantly manual labor and organic fertilizers in the production process. This helps to increase shelf life (of berries, greens), and the final product does not contain foreign impurities and harmful substances. Fresh vegetables, greens, berries, fruits (both fresh and processed), honey, as well as dairy and meat products are the main types of products which can be regarded as organic.

Thus, private peasant farms have a high chance and opportunity to become producers of organic products.

It has been proved that in order to develop their own organic potential and achieve success, private peasant farms of optimal size should enter the legal field and register as individual entities. Self-identification of family farm members by the head of the farm is a common practice in the Member States of the European Union. The emergence of family farms should have a positive impact on the situation in the agricultural sector of Ukraine and the development of rural areas. Now, having entered the legal field, family farms will be able to receive financial assistance under various government programs.

The SWOT analysis revealed the strengths and weaknesses of private farms, as well as external favorable and unfavorable factors for the development of organic farming. A clear and purposeful state policy will contribute to the effective realization of opportunities and elimination of the negative impact of potential threats, in particular: 
- introduction of tax incentives for producers of organic products;

- implementation of the state program for sustainable development of rural areas and "green" tourism;

- implementation of the state program to support the development of rural cooperation;

- elimination of political levers of influence on the implementation of state agricultural policy and the program to support small forms of agricultural producers;

- implementation of the state program to support the development of advisory services in the field of organic production.

The implementation of the proposed measures will increase the number of organic farms and boost the organic production, improve the living conditions of rural people and rural development, increase the competitiveness of the economy and incomes. 


\section{References}

Arbenz, M., Gould, D., Stopes, C. (2016). Organic 3.0 for Truly Sustainable Farming \& Consumption. IFOAM - Organics International \& SOAAN. Retrieved from: https://www. ifoam.bio/sites/default/files/2020-05/Organic3.0_v.2_web.pdf

Bouttes, M., Darnhofer, I., Martin, G. (2018). Converting to Organic Farming as a Way to Enhance Adaptive Capacity. Retrieved from: https://link.springer.com/article/10.1007/ s13165-018-0225-y

Bulavka, L.V. (2012). Osobyste selyanske hospodarstvo yak orhanizatsiyno-pravova forma hospodaryuvannya, yoho sut ta shlyakhy pidvyshchennya efektyvnosti funktsionuvannya. (Private peasant household as an organizational and legal form of management, its essence and ways to increase the efficiency of functioning). Retrieved from: https://www.pdaa.edu. ua/sites/default/files/nppdaa/2011/3_1/053.pdf

Darnhofer, I., Bellon, S., Dedieu, B., Milestad, R. (2010). Adaptiveness to Enhance the Sustainability of Farming Systems. A review. Agronomy for Sustainable Development, No. 30, pp. 545-555. https://doi.org/10.1007/978-94-007-0394-0_4.

European Commission (2008). Commission Regulation (EC) No 889/2008 of 5 September 2008 laying down detailed rules for the implementation of Council Regulation (EC) No. 834/2007 on organic production and labeling of organic products with regard to organic production, labeling and control. Official Journal of the European Union. Retrieved from: https://eur-lex.europa.eu/eli/reg/2008/889/oj.

European Commission (2019). Organic farming in the EU. EU Agricultural Markets Briefs, No. 13, pp. 1-12. Retrieved from: https://ec.europa.eu/info/sites/info/files/food-farming-fisheries/farming/documents/market-brief-organic-farming-in-the-eu_mar2019_en.pdf.

Ikerd, J. (2016). Family farms of North America. International Policy Centre for Inclusive Growth, Working Paper No. 152. Retrieved from: https://ipcig.org/pub/eng/WP152_Family_farms_ of_North_America.pdf

Law of Ukraine No. 436-IV of 07.02.2019. Retrieved from: https://zakon.rada.gov.ua/laws/ show/436-15.

Law of Ukraine No. 2496-VIII on Basic Principles and Requirements for Organic Production, Turnover and Marking of Organic Products of 10.07.2018. Retrieved from: https://zakon. rada.gov.ua/laws/show/2496-19.

Law of Ukraine No. 742-IV on a private peasant household of 05.04.2015. Retrieved from: https://zakon.rada.gov.ua/laws/show/742-15.

Law of Ukraine No. 2497-VIII on amendments to the Tax Code of Ukraine and some laws of Ukraine on stimulating the formation and operation of family farms: of 10.07.2018. Retrieved from: http://zakon.rada.gov.ua/laws/show/2497-19.

Łukasik, W. (2011). Potencjalne kierunki rozwoju gospodarstw rodzinnych $w$ aktualnej sytuacji rynkowej. Wieś i rolnictwo w mediach. Gospodarstwa rodzinne - podstawa europejskiego rolnictwa w odniesieniu do PROW 2007-2013, pp. 41-50. Retrieved from: http://andrzej_ parzonko.users.sggw.pl/minrol.pdf.

Ministry of Agrarian Policy of Ukraine (2020). Orhanichne vyrobnytstvo v Ukrayini. (Organic production in Ukraine). Retrieved from: https://agro.me.gov.ua/ua/napryamki/organichne-virobnictvo/organichne-virobnictvo-v-ukrayini.

Padel, S. (2001). Conversion to Organic Farming: a Typical Example of the Diffusion of an Innovation? Sociologia Ruralis, 41(1), pp. 40-61. https://doi.org/10.1111/1467-9523.00169. 
Regulation (EU) 2018/848 of the European Parliament and of the Council of 30 May 2018 on organic production and labelling of organic products and repealing Council Regulation(EC) No 834/2007. Retrieved from: https://eur-lex.europa.eu/legal-content/EN/TXT/?uri=uriserv\%3AOJ.L_.2018 150.01.0001.01.ENG.

Senyshyn, O., Kundytskyj, O. (2018). Application of SWOT Analysis Method in Forming the Organic Farming Development Strategy as a Basis of Success of the Food Industry in Ukraine. Journal of Management and Finance, Vol. 16, No. 1/1/2018. Retrieved from: http://wzr.ug.edu.pl/.zif/7_16.pdf.

State Fiscal Service of Ukraine (2019). The Total Volume of Imports and Exports in Terms of Product Items by Uktzed Codes. Kyiv: SFSU.

State Statistics Service of Ukraine (2018). Economic statistics / Economic activity / Agriculture, forestry and fisheries. Kyiv: SSSU.

State Statistics Service of Ukraine (2019). Economic statistics / Economic activity / Agriculture, forestry and fisheries. Kyiv: SSSU.

Willer, H., Lernoud J. (2019). The World of Organic Agriculture. Statistics and Emerging Trends 2019. Bonn: Research Institute of Organic Agriculture (FiBL) and IFOAM - Organics International. Retrieved from: https://shop.fibl.org/chen/mwdownloads/download/link/id/1202/. 


\title{
PROBLEMY I PERSPEKTYWY PRODUKCJI EKOLOGICZNEJ W ROLNICTWIE RODZINNYM NA UKRAINIE
}

\begin{abstract}
Abstrakt
Artykut przedstawia problemy rolnictwa ekologicznego na Ukrainie. Badanie wykazało, że drobni producenci z gospodarstw rodzinnych mają zdolność do produkcji produktów ekologicznych spetniajacych odpowiednie wymagania. W pracy przeprowadzono analize SWOT procesu rolnictwa ekologicznego $w$ gospodarstwach rodzinnych, w wyniku której zidentyfikowano główne możliwości i zagrożenia, mocne i stabe strony jego funkcjonowania i rozwoju. Pokazano strategie rozwoju ukraińskiego rolnictwa ekologicznego prywatnych gospodarstw chłopskich, która mogłaby umożliwić dalsze ich funkcjonowanie za pomoca strategicznych kierunków działań, takich jak: wprowadzenie ulg podatkowych dla producentów produktów ekologicznych; realizacja państwowego programu zrównoważonego rozwoju obszarów wiejskich, ,,zielonej” turystyki i wspótpracy na obszarach wiejskich; zniesienie politycznych dźwigni wptywu na realizacje polityki rolnej państwa; realizacja programu wspierajacego rozwój usług doradczych w zakresie produkcji ekologicznej.
\end{abstract}

Słowa kluczowe: prywatne gospodarstwa chłopskie, gospodarstwa rodzinne, produkcja ekologiczna, analiza SWOT, strategia rozwoju.

Accepted for print: 29.09.2020.

Unless stated otherwise all the materials on the website are available under the Creative Commons Attribution 4.0 International license.

Some rights reserved to the Institute of Agricultural and Food Economics - National Research Institute.

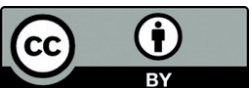

